http://journal.uinsgd.ac.id/index.php/biodjati

\title{
GENETIC PROFILING OF Sida rhombifolia ORIGINATED FROM SEVERAL INDONESIAN ETHNICITIES BASED ON SEQUENCE- RELATED AMPLIFIED POLYMORPHISM MARKERS
}

\author{
Jumailatus Solihah*1, Isma Kurniatanty ${ }^{2}$, Dyah Subositi ${ }^{3}$, Anshary Maruzy ${ }^{4}$, \\ Ika Nugraheni Ari Martiwi ${ }^{5}$, Erny Qurotul Ainy ${ }^{6}$, Khoirul Anam ${ }^{7}$, Aslikh Lana Dina ${ }^{8}$
}

Received : October 21, 2021

Accepted : November 14, 2021

DOI: 10.15575/biodjati.v6i2.14553

1,2,5,6,7,8 Department of Biology, Faculty of Science and Technology, Universitas

Islam Negeri Sunan Kalijaga, Yogyakarta, Jl. Marsda Adisucipto Yogyakarta, 55281

${ }^{3,4}$ Medicinal Plant dan Traditional Medicine Research and Development Center, National Institute of Health Research and Development

e-mail:

*1jumailatus.solihah@uin-suka.ac.id

2isma.kurniatanty@uin-suka.ac.id

3dyah.subositi@gmail.com

4un_sorry03@gmail.com

sika.martiwi@uin-suka.ac.id

6erny.ainy@uin-suka.ac.id

7khoirul.mfa@gmail.com

saslikhlana@gmail.com

*Corresponding author
Abstract. Sida rhombifolia is one of wild flowering plants that grows easily in many habitats with moderate humidity, with some usefulness in traditional medicine. Genetic characterization of Sida rhombifolia accessions originated from 12 ethnicities of Indonesia was analyzed based on Sequence-Related Amplified Polymorphism (SRAP) Markers. The genomic DNA were extracted from leaf samples and then were characterized by using the SRAP marker system. Nine pairs of SRAP primer resulted high polymorphic bands and were used in the genetic profiling. The data analysis was performed using GenAlEx to calculate genetic distance, Principal coordinate analysis, and Analysis of Molecular Variance (AMOVA), also using POPGENE to assess genetic diversity (Hs and $\mathrm{Ht}$ ) and Nm to predict gene flow among populations. The coordinate analysis showed that the accessions originated from ethnicities along Wallacean line tend to differ genetically from most other locations. However, the results of analysis of molecular variance suggested that there were only slight differences (0.1\%) found between ethnicities, while most genetic variances (99.9\%) were found mostly among accessions within populations. The results suggested that there was an extensive genetic flow and plant spreading among Sida rhombifolia plant populations, resulting more homogenous genetic characters among most populations, while high diversity within population. The calculation of the number of migration $(\mathrm{Nm}=1.7341)$ confirmed that the high rate of gene flow had occurred between populations.

Keywords: genetic characterisation, Sida rhombifolia, SRAP

\section{Citation}

Solihah, J., Kurniatanty, I., Subositi, D., Maruzy, A., Martiwi, I. N. A., Ainy, E. Q., Anam, K. \& Dina, A. L. (2021). Genetic Profiling of Sida rhombifolia Originated from Several Indonesian Ethnicities Based on Sequence-Related Amplified Polymorphism Markers. Jurnal Biodjati, 6(2), 203-212..

\section{INTRODUCTION}

Indonesia is one of the countries with the biggest tropical forest in the world. Having massive plant diversity, Indonesia is known as a mega-biodiversity country. The flowering plants spread in the tropical forest more than 30.000 species, and they almost comprise $12 \%$ of the total 250.000 species of flowering plantations in the world (Ersam, 2004). Behind the huge biodiversity, there are potentials of nutritious plants which can be used further. The World Conservation Monitoring Center has reported that there are 


\section{JURNAL BIDDJATI}

http://journal.uinsgd.ac.id/index.php/biodjati

not less than 2.518 plant species in Indonesia which are proved to be useful for various purposes (Kasahara, 1995).

Diversity-based data are crucial especially for natural resources protection, policymaking, and research purposes. Some research on medicinal plants has been performed to generate the database of plant diversity in Indonesia. The research results performed from 2012 to 2017 revealed that at least 2848 plant species have been used traditionally for medicinal purposes (Wahyono et al., 2017). Each species is predicted to have distinctive genetic diversity, considering that they were obtained from different places. Differences in habitat or growing places can affect the biological and chemical properties of plants, such as varieties in morphology, active compound content, and genetic ( $\mathrm{Wu}$ et al., 2013). Therefore, suitable and reliable methods are necessary to generate accurate data and information regarding genetic biodiversity of plants, to facilitate and rationalize the use of medicinal herbs.

Some molecular markers have been used in many studies on genetic diversity or genetic variability either between or among plant populations. The most molecular markers used in the researches include the restriction fragment length polymorphism (RFLP), random amplified polymorphic DNA (RAPD), amplified fragment length polymorphism (AFLP), microsatellite or simple sequence repeats (SSRs), inter simple sequence repeats (ISSRs) (Muthusamy et al., 2008), and a relatively new marker, sequencerelated amplified polymorphism (SRAP) (Li \& Quiros, 2001). The SRAP molecular marker combines the easiness of RAPD and high accuracy as AFLP. It also can detect polymorphisms in coding sequences which have relatively low mutations, so that it is expected to be able to reveal relatively more consistent profiles to differentiate cultivars (Keify \& Beiki, 2012; Zeng et al., 2016).

Sida rhombifolia L., belongs to Malvaceae family, has many local names in Indonesia, such as Saliguri (Minangkabau), Sidaguri (Malay and Central Java), Sidagori (Sunda), Taghuri (Madura), Kahindu (Sumba), Hutu gamo (Halmahera), and Digo (Ternate) (Dalimartha, 2008). It forms an upright herb with strong branches, has a tough stem that is slightly coated with fine hairs, and oval-lanceolate-shaped leaves with little rounded tips and hairs on the leaves surface (Dalimartha, 2008). The plant grows easily in an open area with sufficient sunlight and in places with moderate humidity, like in a yard, open fields and gardens. Some studies mentioned medicinal uses of the plant and revealed many useful bioactive compounds, such as tannins, flavonoids, alkaloids, and terpenoids. In traditional society, some people commonly use this plant to treat gout, prevent inflammation, and it is also known to have efficacy as diuretic and analgetic (Dalimartha, 2008; Hariana, 2013).

Sida rhombifolia and the other plants belonging to Malvaceae family were known as phjhjantropical plants and considered as highly polymorphic taxons (Sivarajan \& Pradeep, 1994). A study by Thul et al. (2011) on molecular characterization and genetic diversity of Sida rhombifolia L. of India has been accomplished by using ISSR marker and showed that 62 polymorphic amplicons were observed from the total 63 bands detected, confirming the high genetic diversity of plant. Although it was considered as a pantropical distributed plant in all tropical areas, including Indonesia, however, the study on genetic variability of this plant species in Indonesia has not been done yet. The study reported here aims to find out the genetic diversity of Sida rhombifolia L. species obtained from several 


\section{JURNAL BIDDJATI}

http://journal.uinsgd.ac.id/index.php/biodjati

ethnicities in Indonesia and molecularly characterize them by using Sequence-related amplified polymorphism (SRAP) marker, and the data obtained are expected to contribute to the database of medicinal plants in Indonesia.

\section{MATERIALS AND METHODS}

A total of 55 Sida rhombifolia L. leaf specimens were used as DNA sources. The leaf samples were collected from 12 ethnicities of some provinces in Indonesia, i.e. Aceh, West Java, South Sumatera, East-South East Kalimantan, Central Sulawesi, South Sulawesi, East Nusa Tenggara, Maluku, and West Papua. The leaf specimen sampling was carried out by Medicinal Plant dan Traditional Medicine Research and Development Center, National Institute of Health Research and Development (Wahyono et al., 2017).

DNA extraction was performed on frozen leaf samples to ease sample lysis. For each sample, as many as $0.05 \mathrm{~g}$ of samples were weighed and groundby using cold mortar and pestle. The DNA extraction was performed according to procedures to do the DNA isolation by using Plant Genomic DNA Purification Mini Kit with some modifications. The modifications were applied on lysis steps by adding $2 \%$ Polyvinylpyrrolidone and $2 \%$ DTT in the Lysis buffer A to reduce viscous substance formation produced by highly mucilaginous plants, then extending incubation 2-3 times longer than the original method to ease DNA extraction from the mucilaginous matrix. After the DNA binding step, the duration of centrifugation was extended to 10 minutes. DNA quantity and purity were known by measuring sample absorbencies at 260 and $280 \mathrm{~nm}$ by using a spectrophotometer. DNA integrity was assessed by running the DNA extracted through gel electrophoresis.

Primer screening was performed on
16 primer combinations. The 16 primer combinations were resulted by combining 4 forward primers (me1, me2, me3, and me4) and 4 reverse primers (em1, em2, em 3 , and em4) according to SRAP marker system by $\mathrm{Li}$ \& Quiros (2001). DNA amplifications using those primer combinations was performed on several DNA samples to get polymorphic bands. The primer combinations resulting polymorphic DNA bands were then selected to be used in DNA amplification for all DNA samples.

DNA amplification was performed as stated by Li \& Quiros (2001). The first five cycles were run after pre-denaturation at $94^{\circ} \mathrm{C}$ for 5 minutes, consisting of denaturation at $94^{\circ} \mathrm{C}$ for 1 minute, annealing at $35^{\circ} \mathrm{C}$ for 1 minute, and extension at $72^{\circ} \mathrm{C}$ for 1 minute. Following the first cycles are 35 cycles by raising the annealing temperature to $50^{\circ} \mathrm{C}$. The extended elongation temperature at $72^{\circ} \mathrm{C}$ for $8 \mathrm{~min}$. was added after the last cycle. The PCR product were then run on $1.5 \%$ agarose gel. The DNA fragments were observed and documented by using UV transilluminator.

DNA fragments observed were measured for their lengths and existences for each accession. The existence of fragments was valued as 1 and the non-existence as 0 . The genetic distances between populations then were measured, Principal coordinate analysis and Analysis of Molecular variances were also determined. The data analyses were performed by using GenAlEx (Peakall \& Smouse, 2012). To assess genetic flow (Nm), the genetic diversity using Nei's (1973) gene diversity statistics was measured, including total gene diversity $(\mathrm{Ht})$, and coefficient of gene differentiation (Gst). The Gene flow, indicated by the number of migrants per generation $(\mathrm{Nm})$ was calculated as $\mathrm{Nm}=$ 0.5 (1-Gst)/4Gst (McDermott \& McDonald, 2003) by using POPGENE (Yeh et al., 1998). 


\section{JURNAL BIODJATI}

http://journal.uinsgd.ac.id/index.php/biodjati

\section{RESULTS AND DISCUSSION}

Total accessions of the plants and their ethnic origins are presented in Table 1. The genomic DNA extracted mostly had a smear appearance indicating fragmented DNA (Figure 1). The high mucilage content of the plant mostly complicated the DNA extraction, resulting in the smeared DNA. The DNA content measured at $260 \mathrm{~nm}$ showed varied results and relatively low concentrations, from $2.0 \mu \mathrm{g} / \mathrm{ml}$ to $45 \mu \mathrm{g} / \mathrm{ml}$, with ratios A260/ A280 1.2 to 1.98 .

Table 1. Amount of Sida rhombifolia L. accessions studied and their ethnicity origins

\begin{tabular}{lll}
\hline Province & \multicolumn{1}{c}{ Ethnicity } & $\begin{array}{c}\text { Accession } \\
\text { Quantities }\end{array}$ \\
\hline Aceh & & 5 \\
& Gayo Serbjadi & 3 \\
West Java & Singkil & 3 \\
Central Java & Betawi & 1 \\
East-Southeast Kalimantan & Yogyakarta & 4 \\
South Sulawesi & Lepo Tau & 5 \\
& Bajau & 4 \\
& Sekko & 1 \\
Central Sulawesi & Konjo & 5 \\
& Duri & 4 \\
South Sumatera & Seko & 2 \\
Maluku & Tomanui & 5 \\
Papua & Lauje & 5 \\
NTT & Tialo & 5 \\
\hline
\end{tabular}
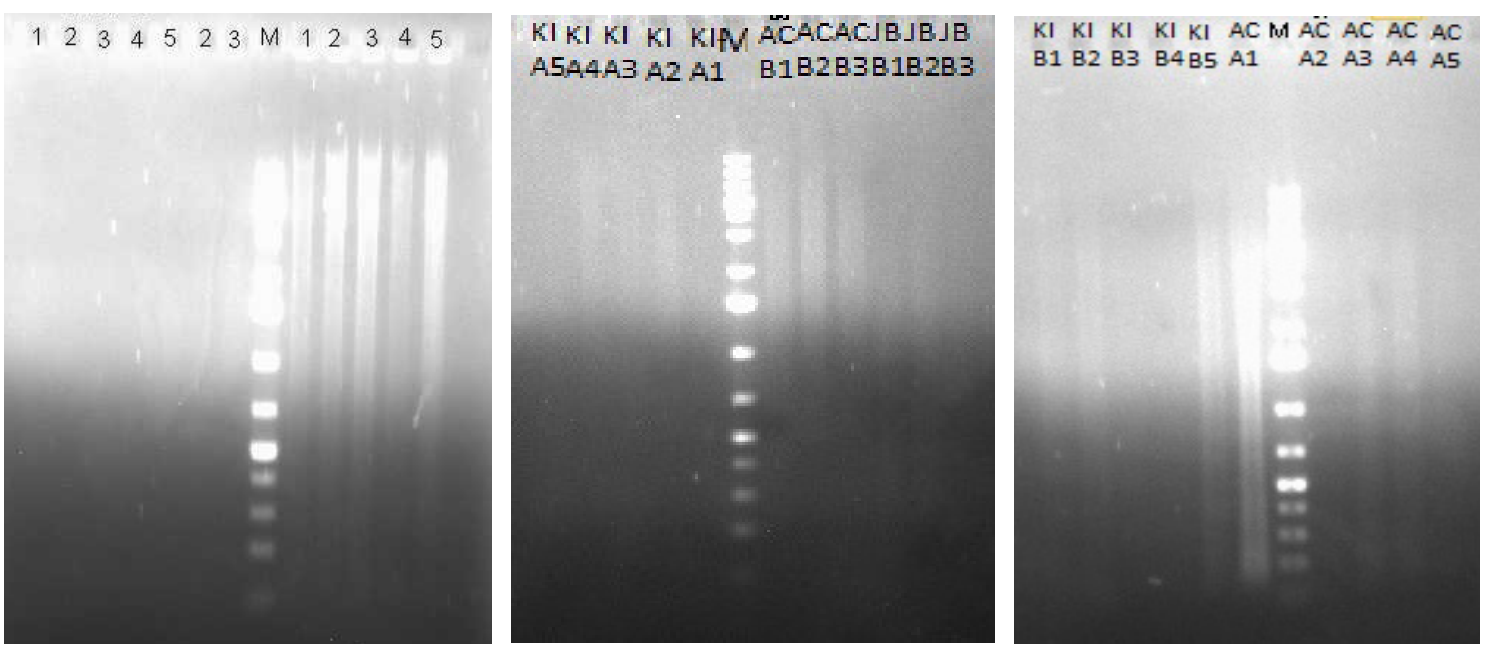

Figure 1. The electrophoresis results showed genomic DNA of Sida rhombifolia L. extracted

The selection of 16 SRAP primer pairs was accomplished by reviewing amplification results on Sida rhombifolia L. accessions. From the primer pair assortment, 9 primer pairs resulted in multi-band amplicons
(Figure 2). The total DNA fragments amplified by using the SRAP markers showed that the SRAP marker used can reveal high DNA polymorphism in Sida rhombifolia L. accessions (Table 2). 


\section{JURNAL BIODJATI}

http://journal.uinsgd.ac.id/index.php/biodjati

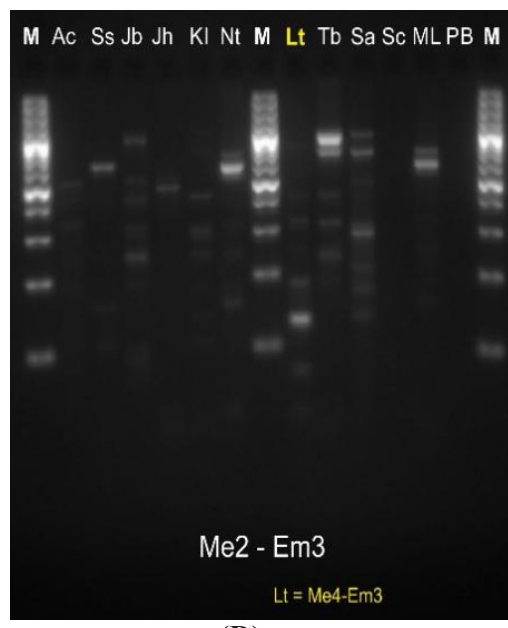

(D)

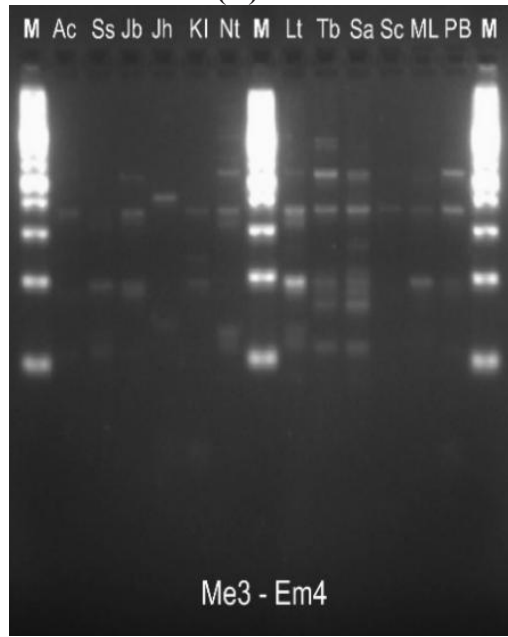

(G)

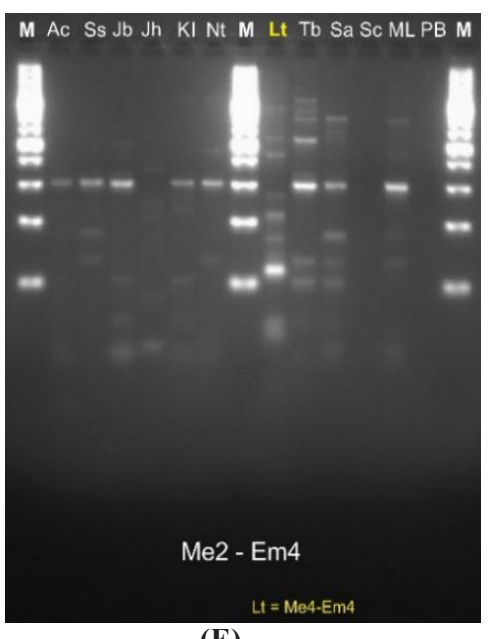

(E)

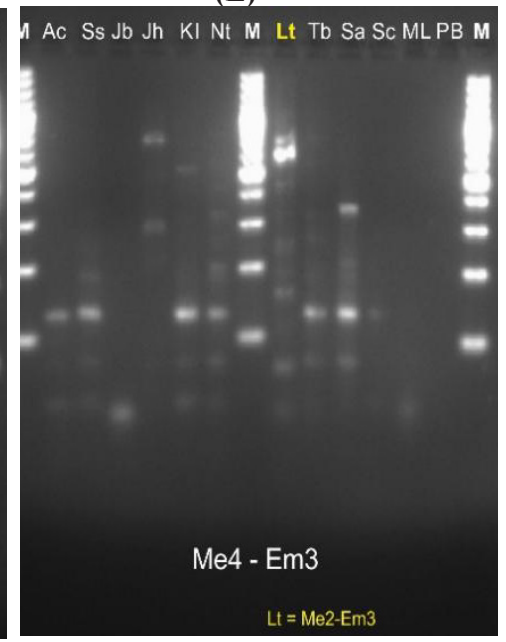

(H)

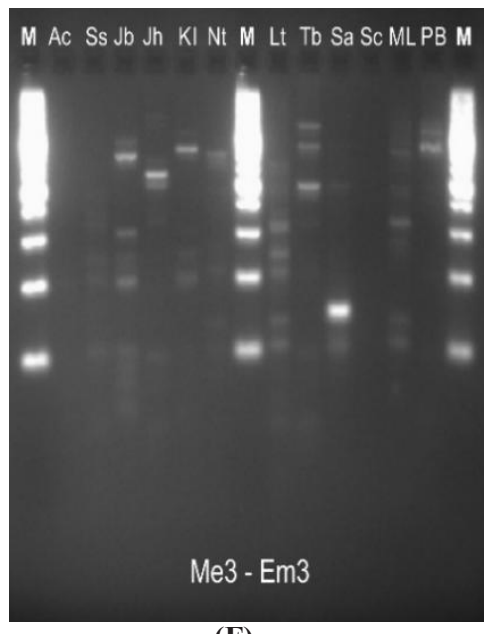

(F)

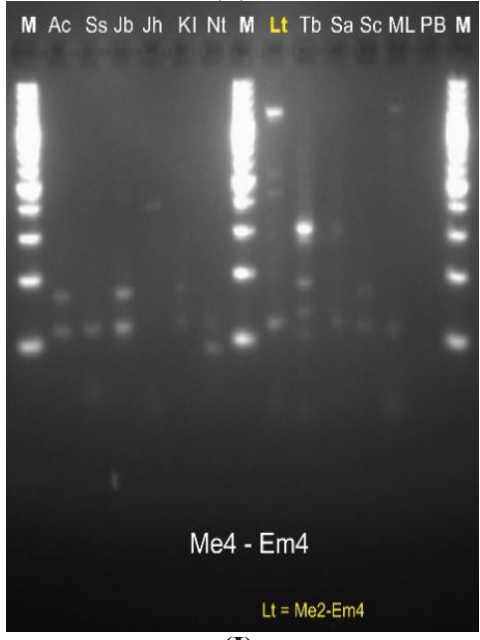

(I)

Figure 2. The polymorphic bands of Sida rhombifolia L. accessions resulted from amplification by using SRAP primer pairs (A to I)

The amplicons resulting from 12 accessions (originated from 12 ethnicities of Indonesia) were analysed using GenAlEx software to find out genetic distances between accessions. The resulted genetic distances showed a range from the lowest distance of 7 to the highest of 79 allele differences from the total of 182 alleles detected (Table 3). It suggested that there are reasonable genetic distances between accessions in Indonesia, but the differences are not unique for certain areas. The closest genetic distance was found between accessions from South Sulawesi (Duri) and accessions from Papua (Waigeo), suggesting a close genetic relationship between plants from the two ethnicities that are relatively far separated geographically, while the highest genetic distance was found between Lauje and Tomanui, both are from Central Sulawesi, but Tomanui is in a small island (Manui) while Lauje is in Sulawesi Island.

The principal coordinate analysis (PCoA) resulted in an interesting result. It indicated that few populations are genetically separated from most populations (Figure 3). Based on the Coordinate Analysis, Plant accessions originated from Central Sulawesi 


\section{JURNAL BIODJATI}

http://journal.uinsgd.ac.id/index.php/biodjati

(Tomanui), South Sulawesi (Sekko), and Maluku (Arafuru) are located at different coordinates that are relatively separated from most other accessions. Also, accessions from East Nusa Tenggara (Ende) and Central Sulawesi (Lauje) are positioned at separated coordinates, compared to other accessions. Those separated accessions are located at coordinates relatively far from each other, and it is known that the ethnic locations where those accessions originated were all distributed along the Wallace line. This fact implies that there is peculiarity as well as genetic diversity among populations in some areas along Wallacean Line, especially for species Sida rombifolia. The genetic distance, represented by far positions in the coordinate, was predicted to result from the genetic drift that happened to some isolated populations that have grown in islands isolated by sea barrier that is still remained along Wallacean line (Welzen et al., 2011).

Table 2. Total DNA fragments resulted from amplification by using SRAP primers

\begin{tabular}{|c|c|c|c|c|}
\hline Primer Pair & Total Amplicons & $\begin{array}{l}\text { Monomorphic } \\
\text { Fragments }\end{array}$ & $\begin{array}{c}\text { Polymorphic } \\
\text { Percentage (\%) }\end{array}$ & Fragmen Sizes (bp) \\
\hline Me $1-$ Em 3 & 19 & 0 & $100 \%$ & $\begin{array}{l}69,74,118,152,177,191,237, \\
253,402,446,540,567,587, \\
612,795,895,994,1072,1280\end{array}$ \\
\hline Me 1 - Em4 & 11 & 0 & $100 \%$ & $\begin{array}{l}108,141,259,357,384,536, \\
559,634,661,764,781\end{array}$ \\
\hline Me 2 - Em 1 & 16 & 0 & $100 \%$ & $\begin{array}{l}57,80,99,115,139,215,245, \\
285,332,378,430,470,533, \\
601,729,817\end{array}$ \\
\hline Me 2 - Em 3 & 30 & 0 & $100 \%$ & $\begin{array}{l}53,57,83,97,114,141,147, \\
161,182,197,202,230,260, \\
324,342,355,446,458,504, \\
514,530,543,617,622,688, \\
712,723,792,818,856\end{array}$ \\
\hline Me 2 - Em 4 & 22 & 0 & $100 \%$ & $\begin{array}{l}47,51,67,105,124,132,178, \\
200,234,243,279,320,358, \\
369,447,468,496,519,576, \\
675,730,847\end{array}$ \\
\hline Me 3 - Em 3 & 33 & 0 & $100 \%$ & $\begin{array}{l}63,78,93,101,107,112,139, \\
142,205,209,219,258,279, \\
327,344,360,388,497,562, \\
586,605,643,664,671,680, \\
716,757,801,835,871,884,\end{array}$ \\
\hline Me 3 - Em 4 & 18 & 0 & $100 \%$ & $\begin{array}{l}108,132,138,163,178,197, \\
250,272,327,366,417,499, \\
528,592,653,703,789,941\end{array}$ \\
\hline Me $4-\operatorname{Em} 3$ & 13 & 0 & $100 \%$ & $\begin{array}{l}49,53,83,130,197,216,258, \\
305,340,446,529,712,792\end{array}$ \\
\hline Me $4-\operatorname{Em} 4$ & 20 & 0 & $100 \%$ & $\begin{array}{l}52,60,96,114,118,140,163, \\
192,221,285,332,421,443, \\
465,519,579,657,730,837, \\
1086\end{array}$ \\
\hline Total & 182 & $\mathbf{0}$ & & \\
\hline Average & 20.22 & $\mathbf{0}$ & & \\
\hline
\end{tabular}




\section{JURNAL BIDDJATI}

http://journal.uinsgd.ac.id/index.php/biodjati

Table 3. Genetic distances between Sida rhombifolia accessions

\begin{tabular}{|c|c|c|c|c|c|c|c|c|c|c|c|}
\hline $\begin{array}{l}\text { Aceh- } \\
\text { Gayo }\end{array}$ & $\begin{array}{c}\text { South } \\
\text { Sumatera- } \\
\text { Meranjat }\end{array}$ & $\begin{array}{l}\text { West } \\
\text { Java- } \\
\text { Betawi }\end{array}$ & $\begin{array}{c}\text { Central } \\
\text { Java- } \\
\text { Jogja }\end{array}$ & $\begin{array}{c}\text { Southeast } \\
\text { Kalimantan- } \\
\text { Bajau }\end{array}$ & $\begin{array}{l}\text { East } \\
\text { NT- } \\
\text { Ende }\end{array}$ & $\begin{array}{l}\text { Central } \\
\text { Sulawesi- } \\
\text { Lauje }\end{array}$ & $\begin{array}{l}\text { Southeast } \\
\text { Sulawesi- } \\
\text { Tomanui }\end{array}$ & $\begin{array}{c}\text { South } \\
\text { Sulawesi- } \\
\text { Sekko }\end{array}$ & $\begin{array}{l}\text { South } \\
\text { Sulawesi- } \\
\text { Duri }\end{array}$ & $\begin{array}{l}\text { Maluku- } \\
\text { Alfuru }\end{array}$ & $\begin{array}{c}\text { West } \\
\text { Papua } \\
\text {-Waigeo }\end{array}$ \\
\hline \multicolumn{12}{|c|}{ 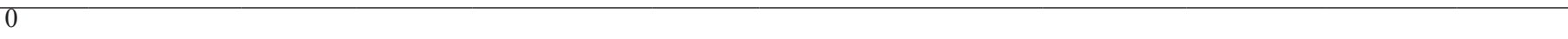 } \\
\hline 34 & 0 & & & & & & & & & & \\
\hline 42 & 38 & 0 & & & & & & & & & \\
\hline 41 & 49 & 61 & 0 & & & & & & & & \\
\hline 34 & 40 & 38 & 59 & 0 & & & & & & & \\
\hline 52 & 50 & 70 & 73 & 64 & 0 & & & & & & \\
\hline 64 & 66 & 72 & 73 & 74 & 52 & 0 & & & & & \\
\hline 65 & 61 & 71 & 72 & 69 & 65 & 79 & 0 & & & & \\
\hline 52 & 48 & 66 & 65 & 58 & 58 & 74 & 53 & 0 & & & \\
\hline 20 & 30 & 38 & 29 & 36 & 48 & 56 & 57 & 46 & 0 & & \\
\hline 56 & 50 & 62 & 61 & 64 & 52 & 72 & 59 & 56 & 42 & 0 & \\
\hline 25 & 31 & 39 & 28 & 41 & 51 & 59 & 56 & 47 & 7 & 43 & 0 \\
\hline
\end{tabular}

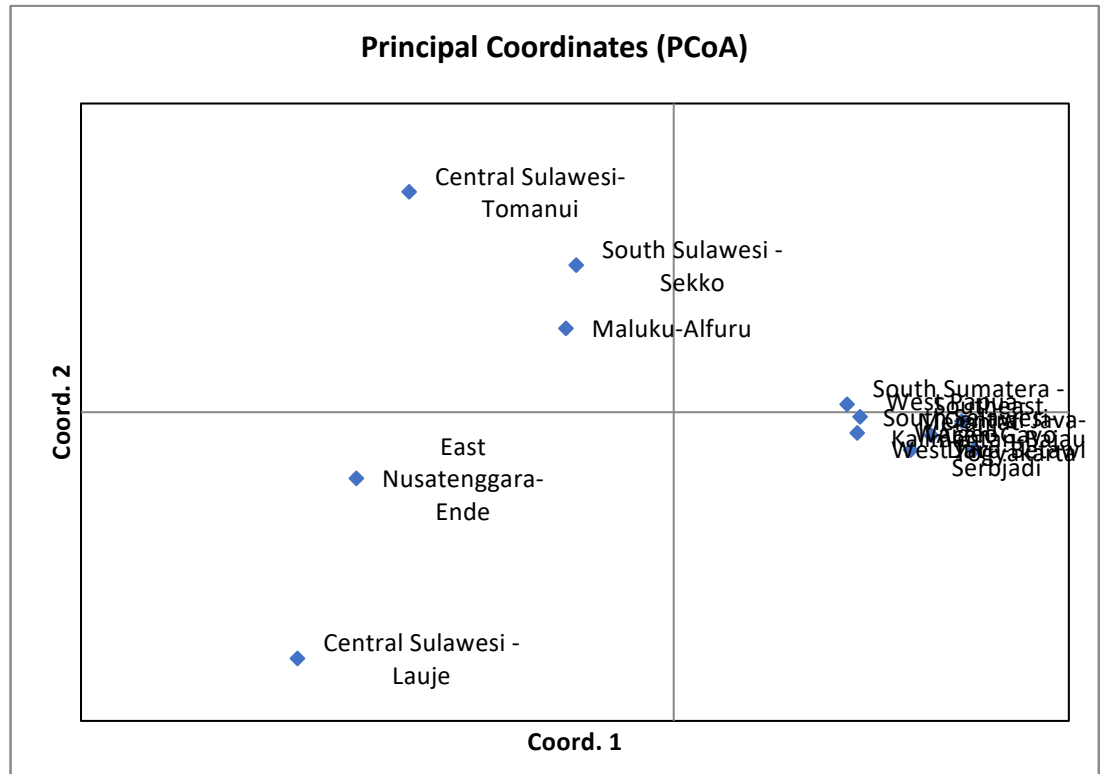

Figure 3. Principal Coordinate Analysis of Sida rhombifolia plants originated from several ethnicities in Indonesia

On the other hand, plant accessions originated from ethnicities in Java, Sumatera, and Kalimantan as well as Papua, those are relatively far from Wallacean line, tend to have more similar genetic characteristics, revealed from the clustered accessions in a narrow area in the coordinate. The genetic similarity between accessions is predicted to be related to the genetic flow that happened between plant populations. The facts that even Jurnal Biodjati 6(2):203-212, November 2021 the geographically far separated accessions from West Papua (Waigeo), that is in Eastern Indonesia (on the Sahul shelf), have relative similar genetic characters with those from western Indonesian islands (Java, Sumatera, Kalimantan) on Sunda shelves, suggested that the genetic flow also can happen between far separated area. The genetic flow can be assisted by people's movement between those areas. This fact on Sida rhombifolia 


\section{JURNAL BIDDJATI}

http://journal.uinsgd.ac.id/index.php/biodjati

genetic characteristics is also concomitant to the study by Welzen et al. (2011) on plants distribution in Indonesia, which stated that the plant distribution in Sunda-Sahul shelves tend to be more homogenous, while the plants in Wallacean area are more heterogeneous.

Overall, the genetic characteristic of Sida rhombifolia plants from several ethnicities in Indonesia based on SRAP marker showed that the species has a relatively high genetic variation and showed genetic differences among accessions in populations. This is also revealed by the result of analysis of molecular variance (AMOVA) that suggested that the genetic variability of Sida rhombifolia plants mainly results from genetic heterogeneity among accessions (AMOVA 100\%), and there is no specific genetic peculiarity that significantly differs between populations (Figure 4). A little genetic variability between populations, showed by the estimated variance of $0.1 \%$, indicated that there are only $0.1 \%$ of populations underwent genetic drift, because the genetic drift represents the main source of genetic diversity among populations (Porth \& El-Kassaby, 2014).

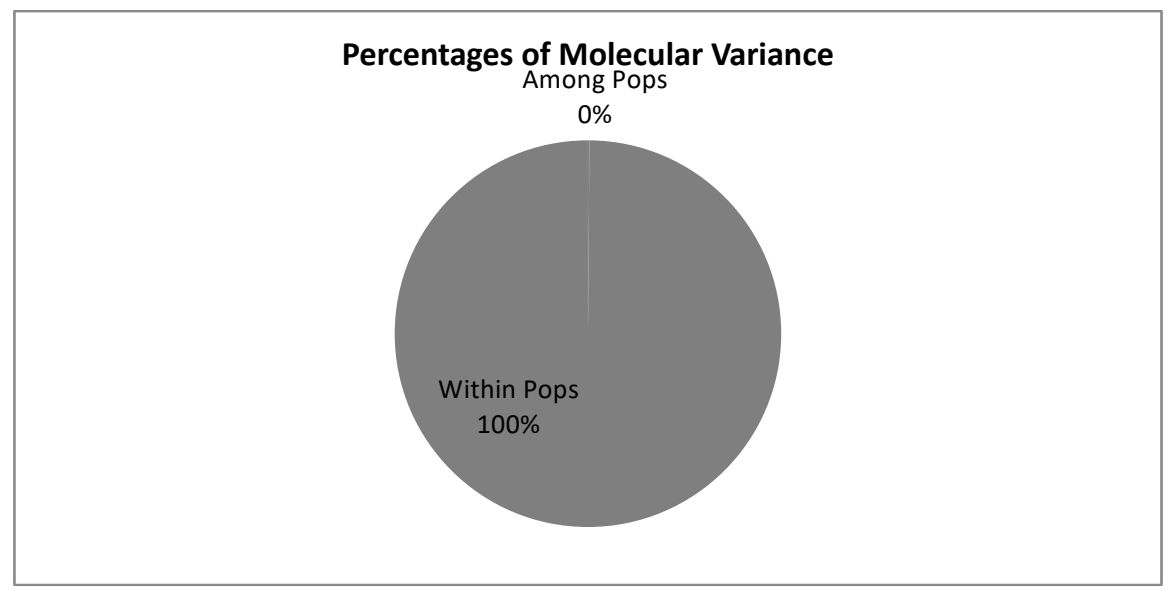

Figure 4. Analysis of Molecular Variance of Sida rhombifolia plants from several ethnicities in Indonesia

On the other hand, the high proportion of genetic variation within populations (99.9\%) showed high heterogeneity among accessions and it can be caused by the introduction of new alleles from other populations, representing high genetic flow occurred between populations (Porth \& El-Kassaby, 2014). The dominance of intra-population genetic diversity is also supported by the calculation of Hs (0.1905) from total genetic diversity $\mathrm{Ht}$ of 0.2454 (Table 4), based on Nei's analysis of gene diversity (Nei, 1987).

The indication of a high genetic flow rate among Sida rhombifolia plants was revealed by the migrant numbers (Nm) resulting from the data analysis that is higher than $1(\mathrm{Nm}=1.7341)$, indicating that the gene flow was adequate to negate the genetic drift effects (Table 4). This high genetic flow among populations of Sida species was feasible because some species of Sida genus, including Sida rhombifolia species, are included in invasive species, and their seeds can be easily attached to animal's fur or human's clothes/vehicles that assist their wide-spreading (Setyawati et al., 2015). 


\section{JURNAL BIDDJATI}

http://journal.uinsgd.ac.id/index.php/biodjati

Table 4. Nm calculation indicates Gene Flow of Sida rhombifolia

\begin{tabular}{lcccc}
\hline & Ht & Hs & Gst & Nm \\
\hline Mean & 0.2454 & 0.1905 & 0.2238 & 1.7341 \\
St. Deviation & 0.0182 & 0.0117 & &
\end{tabular}

Number of polymorphic loci is: 182

The percentage of polymorphic loci is: 100.00

$\mathrm{Ht}=$ total genetic diversity

$\mathrm{Hs}=$ genetic diversity within populations

Gst $=$ the coefficient of gene differentiation

$\mathrm{Nm}=$ estimate of gene flow from Gst $=0.5(1-\mathrm{Gst}) / \mathrm{Gst}(\mathrm{J} \mathrm{M}$ McDermott \& McDonald, 1993)

\section{ACKNOWLEDGMENTS}

We would like to thank many parties supported the completion of work. We thank the dean of Faculty of Science and Technology UIN Sunan Kalijaga Yogyakarta for supporting the collaboration held between institutions. We also thank Mrs. Anif Yuni Muallifah for her dedicated technical support in the laboratory, also for Ms Sutan Nur Chamida, Ms. Sunni Sofia Aniqah, and Ms. Fatin Muniroh Syauqi for the technical assistance in the laboratory. We also thank the team from The Research and Development Center for Medicinal and Traditional Plant for the great collaboration, the research was completely done by funding from the project Riset Tanaman Obat dan Jamu (RISTOJA) by The Research and Development Center for Medicinal and Traditional Plant, Ministry of Health, Indonesia.

\section{REFERENCES}

Dalimartha, S. (2008). Atlas tumbuhan obat Indonesia. Jakarta: Trubus Agriwidya.

Ersam, T. (2004). Tumbuhan Sebagai Model Senyawa Kimia. Prosising, Seminar Nasional Kimia VI. FMIPA Institut Teknologi Sepuluh Novemper (ITS).

Hariana, A. (2013). 262 tumbuhan obat dan khasiatnya. Jakarta: Penebar Swadaya.

McDermott, J. M. \& McDonald, B. A. (1993). Gene Flow in Plant Pathosystems. Annu.
Rev. Phytopathol., 31, 353-373.

Kasahara, Y. S. (1995). Medicinal Herb Index in Indonesia (Y. S. Kasahara \& S. Mangunkawatja (eds.). PT. Eisai Indonesia.

Keify, F. \& Beiki, A. H. (2012). Exploitation of random amplified Polymorphic DNA (RAPD) and Sequence-related amplified Polymorphism (SRAP) Markers for Genetic Diversity of Saffron Collection. Journal of Medicinal Plants Research, 6(14), 2761-2768.

Li, G. \& Quiros, C. F. (2001). Sequence-related Amplified Polymorphism (SRAP), a New Marker System Based on a Simple PCR Reaction: its Application to Mapping and Gene Tagging in Brassica. Theoretical and Applied Genetics, 103(2), 455-461.

McDermott, J. M. \& McDonald, B. A. (2003). Gene Flow in Plant Pathosystems. Retrieved from Http:// Dx.Doi.Org/10.1146/Annurev. Py.31.090193.002033, 31, 353-373.

Muthusamy, S., Kanagarajan, S., \& Ponnusamy, S. (2008). Efficiency of RAPD and ISSR Markers System in Accessing Genetic Variation of Rice Bean (Vigna Umbellata) Landraces. Electronic Journal of Biotechnology, 11(3), 717-3458.

Nei, M. (1987). Molecular Evolutionary Genetics. In Molecular Evolutionary Genetics. USA: Columbia University 


\section{JURNAL BIDDJATI}

http://journal.uinsgd.ac.id/index.php/biodjati

Press.

Peakall, R. \& Smouse, P. E. (2012). GenAlEx 6.5: genetic analysis in Excel. Population genetic software for teaching and research-an update. Bioinformatics, 28(19), 2537-2539.

Porth, I. \& El-Kassaby, Y. A. (2014). Assessment of the Genetic Diversity in Forest Tree Populations Using Molecular Markers. Diversity, 6(2), 283-295.

Setyawati, T., Narulita, S., Bahri, I. P. \& Raharjo, G. T. (2015). A Guide Book to Invasive Alien Plant Species in Indonesia (T. Partomihardjo, S. Tjitrosoedirdjo, \& Sunaryo (eds.). Research Development and Innovation Agency, Ministry of Environment and Forestry. Retrieved from http://ksdae.menlhk.go.id/ assets/publikasi/A_Guide_Book_of_ Invasive_Plant_Species_in_Indonesia. pdf.

Sivarajan, V. V. \& Pradeep, A. K. (1994). Taxonomy of The Sida rhombifolia (Malvaceae) Complex in India . JSTOR, 16(1), 63-78.

Thul, S., Srivastava, A., Singh, S., \& Shanker, K. (2011). Genetic and Chemical Diversity of High Mucilaginous Plants of Sida complex by ISSR Markers and Chemical Fingerprinting. Molecular Biotechnology, 49(1), 77-81.

Wahyono, S., Jokopriyambodo, W., Mustofa, F. I., Rahmawati, N., Sari, A. N., Maruzy, A., Mujahid, R., Widowati, L., Widiyastuti, Y., Subositi, D., Budiarti,
M., Haryanti, S. \& Junediyono. (2017). Eksplorasi Pengetahuan Lokal Etnomedisin dan Tumbuhan Obat Berbasis Komunitas di Indonesia. Report. [Unpublish].

Welzen, P. C. van, Pernell, J. A. N. \& Slik, J. W. F. (2011). Wallace's Line and Plant Distributions: Two or Three Phytogeographical Areas and where to Group Java? Biological Journal of the Linnean Society, 103(3), 531-545.

Wu, Y., Zheng, L., Yi, J., Wu, J., Chen, T.,\& Wu, J. (2013). Quantitative and Chemical Fingerprint Analysis for the Quality Evaluation of Receptaculum Nelumbinis by RP-HPLC Coupled with Hierarchical Clustering Analysis. International Journal of Molecular Sciences, 14(1), 1999-2010.

Yeh, F. C., Yang, R.-C., Boyle, T. B. J., Ye, Z.H., \& Mao, J. X. (1998). POPGENE, the User-friendly Shareware for Population Genetic Analysis. Journal of Heredity. Retrieved from https://sites.ualberta. $\mathrm{ca} /$ fyeh/faqs.html.

Zeng, B., Wang, G., Zuo, F., Chen, Z. \& Zhang, X. (2016). Genetic Diversity Analysis of Cocksfoot (Dactylis glomerata L.) Accessions with Sequence-related Amplified Polymorphism (SRAP) and Inter-Simple Sequence Repeat (ISSR) Markers. African Journal of Biotechnology, 11(67), 13075-13084. 